\title{
A First Record of Whip Lobsters Puerulus sewelli from Oman with Notes on Size, Condition and Length-Weight Relationships
}

\author{
Abdullah Al-Nahdi*1, Abdulaziz Al-Marzouqi', Johan C. Groeneveld ${ }^{1}$ \\ and Ahmed Al-Hosni² \\ ${ }^{1}$ Marine Science and Fisheries Centre, P.O. Box 227 \\ PC 100, Muscat, Sultanate of Oman \\ ${ }^{2}$ Ministry of Fisheries Wealth, P.O. Box 427 \\ PC 100, Muscat, Sultanate of Oman
}

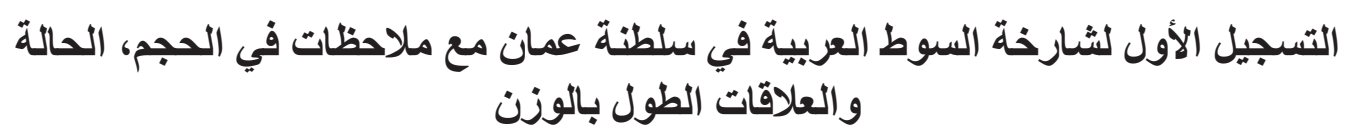

عبدالله النهدي، عبدالعزيز المرزوقي ، جوهان جرونفليد وأحمد الحوسني

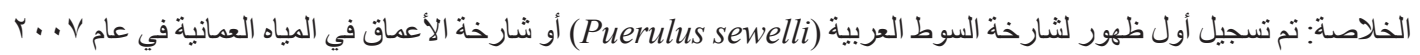

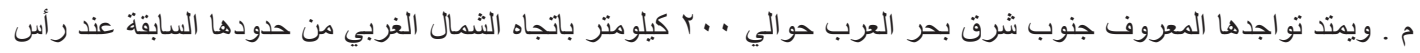

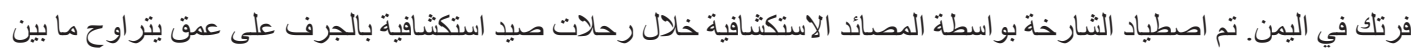
.

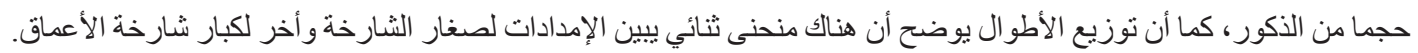

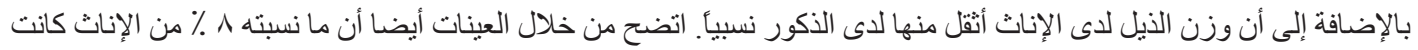

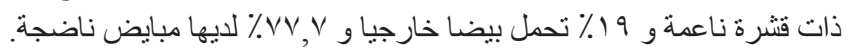

ABSTRACT: Arabian whip lobsters Puerulus sewelli were for the first time reported from the waters of Oman in 2007 , extending its known range along the southeastern coast of the Arabian Peninsula by $\sim 200 \mathrm{~km}$ northeastwards from its previous boundary at Ras Fartak in Yemen. The lobsters were caught in exploratory trawls at 230-787 m depth. The size of 67 lobsters ranged from 51-87 mm CL (31.4-161.7 $\mathrm{g}$ whole weight, WW). Females were larger than males. The size distribution was bimodal, showing recent recruits and post-recruits. Female tail weight (TW) became progressively heavier than male TW, relative to increasing, but equivalent $\mathrm{CL}$ or WW-values. Of the females, $8 \%$ were soft-shelled, $19 \%$ carried external eggs, and $77.7 \%$ had maturing or ripe gonads.

Keywords: Puerulus sewelli, size, Oman.

\section{Introduction}

The Arabian whip lobster, Puerulus sewelli Ramadan, 1938 (family: Palinuridae) (Fig. 1) has patchy distribution in the Indian ocean region especially in the waters of Somalia, the Gulf of Aden, Yemen, Pakistan, and SW coast of India and the Gulf of Mannar (Fischer and Bianchi, 1984, Holthuis, 1991). In the present paper, the occurrence of $P$. sewelli in the waters of Oman is reported for the first time. The lobsters were caught during an exploratory demersal trawl survey conducted in October and December 2007 at depths between 230 and $787 \mathrm{~m}$.

Puerulus sewelli has been of considerable interest to fisheries (Holthuis, 1991). In 1974-1977 and 1983 it was commercially fished off eastern Somalia (Johnsen, 1985), and in the Gulf of Aden experimental trawling returned average catches of $10-129 \mathrm{~kg} / \mathrm{h}$. Off SW India rich fishing grounds were found and in the Gulf 


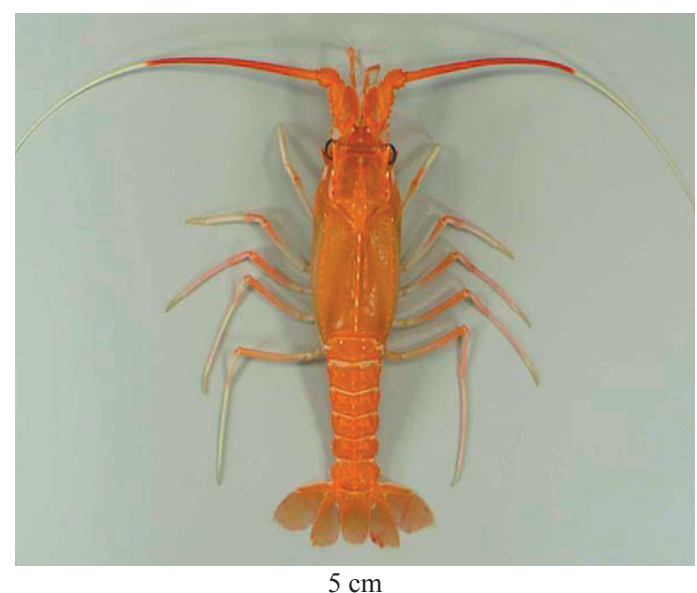

Figure 1. P. sewelli collected off Oman.

of Mannar it was available in varying quantities along the depth belt of 150-500 m (see www.fsi.gov.in). Off Yemen, a trawl fishery in the 1970s landed between 112 and $428 \mathrm{t}$ annually, but this fishery seems to have collapsed by 1993 (Sanders, 1981; Anon., 2004), and no catches were reported for 2000-2002.

Biological information on Puerulus sewelli is scattered among various unpublished reports (Sanders, 1981; Johnsen, 1985) and fisheries survey bulletins (see www.fsi.gov.in). Notably, it inhabits a substrate of coarse sand, hard mud and shells, reaches a maximum total body length of about $200 \mathrm{~mm}$ (average of $150 \mathrm{~mm}$ ), grows fast, and has a mean lifespan of 3 years while in the exploited phase (Sanders, 1981; Holthuis, 1991).

The aims of this study were to report on the geographical range extension, and provide information on the size, composition, length-weight relationships, and the reproductive condition of $P$. sewelli in a sample taken in Oman.

\section{Materials and Methods}

Exploratory trawls at depths $>230 \mathrm{~m}$ were executed during daylight on the 10th of November (2 trawls) and the 8th of December 2007 (1 trawl), in the region between Mirbat and the Yemen border. A trawl net with an $18 \mathrm{~mm}$ mesh in the codend was used, and the start and end points of each trawl that caught $P$. sewelli, depth range, trawl speed, distance between trawl doors and duration of trawls are shown in Table 1. CTD drops were made at the end of each trawl to determine bottom temperature.

Captured lobsters were frozen on-board and transferred to the MSFC laboratory. After defrosting, the total length ( $\mathrm{TL} \pm 1 \mathrm{~mm}$; from the ridge between the eyes to the tip of the uropod) and carapace length $(\mathrm{CL} \pm 1 \mathrm{~mm}$; ridge between the eyes to the posterior edge of the carapace) of each lobster were measured using Vernier calipers, and the whole weight (WW $\pm 1 \mathrm{~g})$ and tail weight (TW $\pm 1 \mathrm{~g}$ ) determined. Linear regressions were fitted to CL versus TL, and WW versus TW, and non-linear regressions to $\mathrm{CL}$ versus TW and CL versus WW using a least-squares algorithm in Microsoft Excel.

Gender was determined from external characteristics, and female gonads were categorized into one of four groups based on colour: stage 1 or immature - white; stage 2 or developing - yellow to very light orange; stage 3 or maturing - orange; and stage 4 or ripe - red (Groeneveld and Melville-Smith,

Table 1. GPS readings at the start and end of three exploratory trawls, depth, trawl speed, and duration of trawls and the distance between trawl doors and lobster catch.

\begin{tabular}{lcccccc}
\hline Start trawl & End trawl & $\begin{array}{c}\text { Depth } \\
(\mathbf{m})\end{array}$ & $\begin{array}{c}\text { Trawl } \\
\text { speed } \\
(\mathbf{k n o t s})\end{array}$ & $\begin{array}{c}\text { Distance } \\
\text { between trawl } \\
\text { doors }(\mathbf{m})\end{array}$ & $\begin{array}{c}\text { Duration } \\
\text { of trawl } \\
(\mathbf{m i n})\end{array}$ & $\begin{array}{c}\text { Lobster } \\
\text { catch } \\
(\mathbf{k g})\end{array}$ \\
\hline $16^{\circ} 44^{\prime} 68 \mathrm{~N}$ & $16^{\circ} 44^{\prime} 04 \mathrm{~N}$ & $253-399$ & 3.5 & 110.45 & 19 & $<1$ \\
$53^{\circ} 57^{\prime} 41 \mathrm{E}$ & $53^{\circ} 58^{\prime} 43 \mathrm{E}$ & & & & & \\
$16^{\circ} 43^{\prime} 73 \mathrm{~N}$ & $16^{\circ} 42^{\prime} 79 \mathrm{~N}$ & $442-787$ & 3.5 & 116.30 & 30 & 1.8 \\
$53^{\circ} 59^{\prime} 10 \mathrm{E}$ & $54^{\circ} 00^{\prime} 07 \mathrm{E}$ & & & & \\
$16^{\circ} 44^{\prime} 72 \mathrm{~N}$ & $16^{\circ} 44^{\prime} 02 \mathrm{~N}$ & $230-410$ & 3.3 & 95.85 & 20 & 6.4 \\
$53^{\circ} 57^{\prime} 18 \mathrm{E}$ & $53^{\circ} 58^{\prime} 32 \mathrm{E}$ & & & & & \\
\hline
\end{tabular}


Table 2. Comparison of average ( \pm S.D.), minimum and maximum CL, TL, WW and TW of male, female and all P. sewelli caught in exploratory trawls in 2007. Sample size shown in parenthesis.

\begin{tabular}{lcccc}
\hline Variable & Gender & Average \pm S.D. & Minimum & Maximum \\
\hline CL $(\mathrm{mm})$ & All $(67)$ & $69.7 \pm 8.8$ & 51 & 87 \\
& F $(37)$ & $72.0 \pm 9.0$ & 52 & 87 \\
& M $(30)$ & $66.8 \pm 7.8$ & 51 & 77 \\
TL $(\mathrm{mm})$ & All & $159.6 \pm 18.6$ & 119 & 195 \\
& F & $166.8 \pm 18.7$ & 124 & 195 \\
& M & $151.2 \pm 14.9$ & 119 & 172 \\
WW $(\mathrm{g})$ & All & $83.7 \pm 28.8$ & 31.4 & 161.7 \\
& F & $91.9 \pm 31.1$ & 31.4 & 161.7 \\
TW $(\mathrm{g})$ & M & $73.2 \pm 21.7$ & 34.0 & 112.4 \\
& All & $26.6 \pm 10.5$ & 11.1 & 53.6 \\
& F & $31.6 \pm 11.1$ & 11.9 & 53.6 \\
& M & $20.5 \pm 5.2$ & 11.1 & 32.5 \\
\hline
\end{tabular}

1994). The proportions of females with ovaries in stages 2-4 per 2-mm size class were fitted to a logistic equation of the form $\mathrm{P}=1 /(1+\exp (\mathrm{a}-\mathrm{bTL})$ where $\mathrm{P}$ is the proportion of mature females in each length class and $\mathrm{a}$ and $\mathrm{b}$ are constants, and the $\mathrm{CL}$ at $50 \%$ maturity determined.

\section{Results and Discussion}

The easternmost point at which $P$. sewelli was previously recorded on the southeastern Arabian continental slope was off Ras Fartak in Yemen $\left(15^{\circ} 35^{\text {, }}\right.$ N $52^{\circ} 12^{\prime} \mathrm{E}$ (Sanders, 1981). The exploratory trawls in Oman encountered the species up to $16^{\circ} 42^{\prime} \mathrm{N} 54^{\circ} 00^{\prime}$
E, thus extending its known range by approximately $200 \mathrm{~km}$ northeastwards. The depth range covered in the exploratory trawls off Oman $(230-787 \mathrm{~m})$ was similar to the $200-600 \mathrm{~m}$ range where $P$. sewelli was most often fished in Yemen (Sanders, 1981). Bottom water temperatures in Oman were $12.6^{\circ} \mathrm{C}, 12.4^{\circ} \mathrm{C}$ and $13.6^{\circ} \mathrm{C}$ for the three trawls, and the trawlable area (i.e. soft substrate without significant reefs) was small, based on acoustic data collected during the survey using the vessel's hull-mounted $38 \mathrm{kHz}$ transducer. Additional data on bycatches and CTD information are stored on the survey database under Oma0701, for station numbers 318-321, and Oma0702, station numbers 379 and 380 .

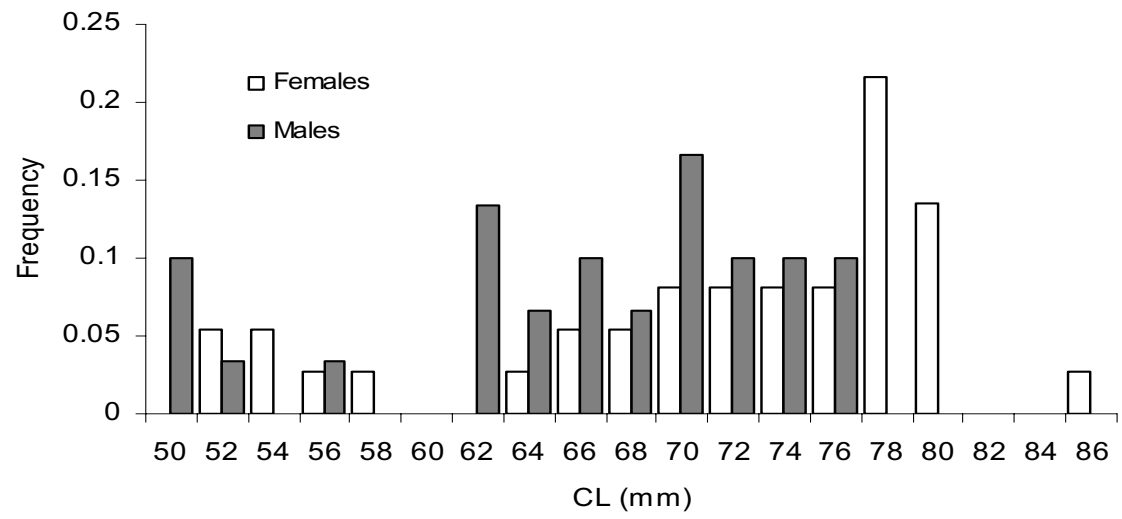

Figure 2. Size frequency distribution (CL, mm) of male and female P. sewelli caught in Oman in 2007. 

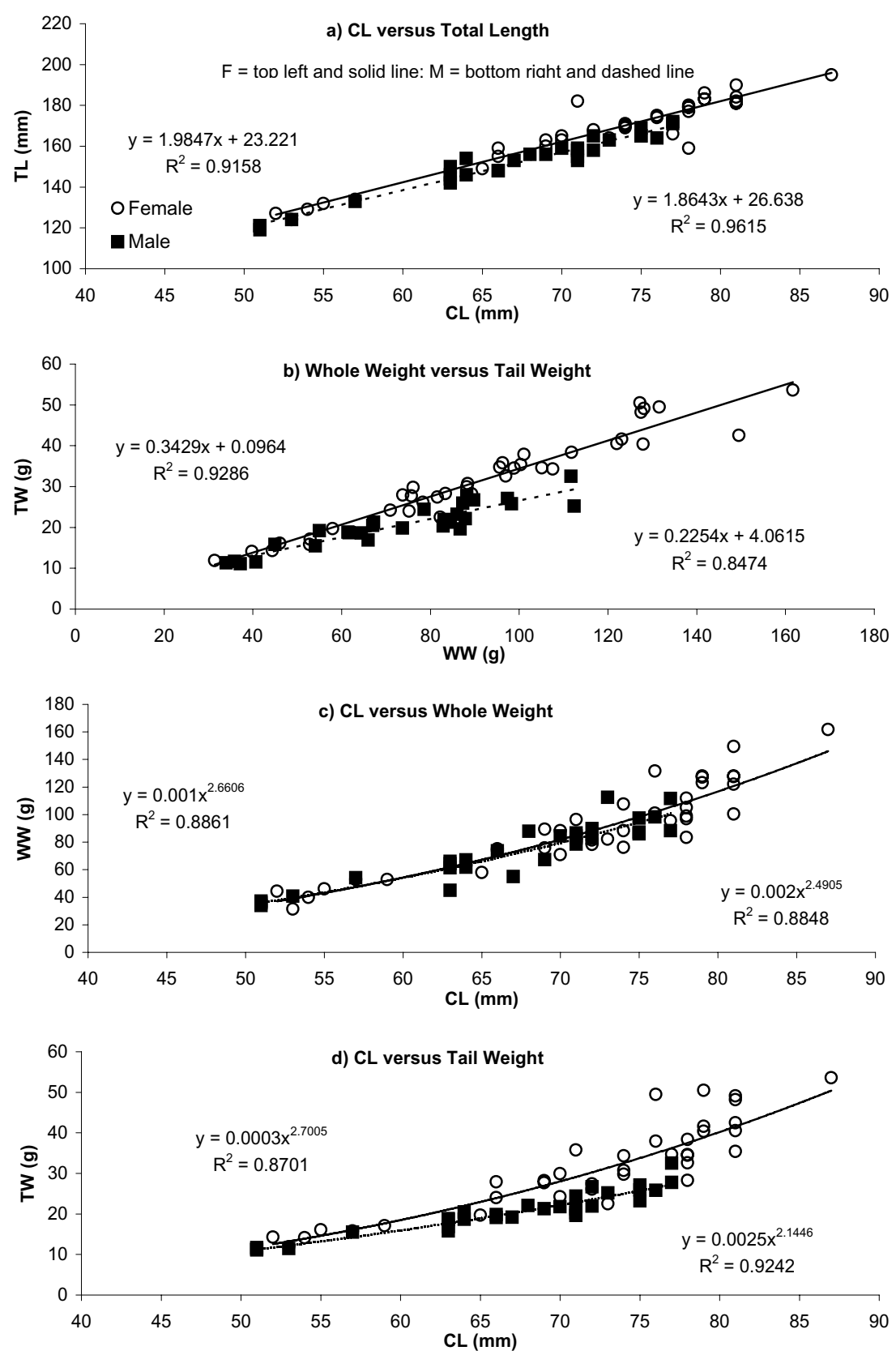

Figure 3. Regressions of (a) CL versus TL, (b) WW versus TW, (c) CL versus WW, and (d) CL versus TW of 37 female and 30 male $P$. sewelli. The equations and $\mathrm{R}^{2}$ are shown. 
A total of 67 lobsters, 37 females and 30 males (a ratio of 1:0.81) $(6.4 \mathrm{~kg})$, were collected from the trawl made on $8^{\text {th }}$ December, The size of specimens ranged from $51-87 \mathrm{~mm}$ CL (119-195 mm TL), with an average of $69.7 \pm 8.8$ (S.D.) mm CL (159.6 $\pm 18.7 \mathrm{~mm}$ TL) (Table 2). The average CL of females $(71.9 \pm 9.0 \mathrm{~mm})$ was larger than that of males $(66.8$ $\pm 7.8 \mathrm{~mm}$ ), and $38 \%$ of females were larger than the maximum size of $77 \mathrm{~mm}$ CL measured for males (Fig. 2). This result is consistent with that of Sanders (1981) from Yemen, where females grew to a "considerably larger length than males". The largest length class from Somalia was $215 \mathrm{~mm}$ TL (Johnsen, 1986) and in Yemen the largest individual measured was $205 \mathrm{~mm}$ TL (Sanders, 1981).

The size frequency distribution suggests two modes, at $54 \mathrm{~mm}$ and $72 \mathrm{~mm}$ CL respectively (Fig. 2), very similar to modes at $52.8 \mathrm{~mm}$ and $72.4 \mathrm{~mm}$ CL reported by Sanders (1981) for a sample taken in December 1972 (the same month as in the present study) in Yemen. The latter author suggested that the smaller lobsters (recruits) moved into the fishery in autumn, and that the larger lobsters (post-recruits) consist of cohorts recruited in the spring of the same year, and earlier.

The linear regressions of CL versus TL for males and females respectively fitted the data well, with high coefficients of variation $\left(r^{2}>0.91\right.$; Fig. 3a). For sexes combined, the equation was $\mathrm{TL}=2.0238 \times \mathrm{CL}+18.352$ $\left(r^{2}=0.93\right)$, and this equation was used above to convert data from Yemen (given in TL in Sanders, 1981) to CL for comparisons with the present data from Oman. The linear regressions of WW versus TW fitted the data well $\left(r^{2}=0.85\right.$ for males and 0.93 for females; Fig. $\left.3 b\right)$, showing that the TW proportion of females increase faster than that of males as lobsters increase in WW. This is a common occurrence in many lobster species (Groeneveld, 1996).

Regressions of CL versus WW and CL versus TW are useful for raising the length composition of biological subsamples to reflect that of total catches in biomass calculations. The non-linear regressions of CL versus WW are shown for males $\left(r^{2}=0.89\right)$ and females $\left(r^{2}=0.88\right)$ in Fig. 3c. Similar regressions of CL versus TW are shown for males $\left(r^{2}=0.87\right)$ and females $\left(r^{2}=0.92\right)$ in Fig. 3d, and the latter regressions confirm that the TW of females becomes progressively heavier than that of males as CL increases.

Three females were soft-shelled ( $8 \%)$, indicating that they had recently moulted, but none of the males were soft. Based on the visual examination of 36 excised female gonads, $8.3 \%$ were immature (ave. CL $=53 \mathrm{~mm}), 13.8 \%$ were developing $(75.6 \mathrm{~mm}), 55.5 \%$ were maturing $(73.7 \mathrm{~mm})$ and $22.2 \%$ were ripe $(72.6$ $\mathrm{mm})$. Seven females (19\%) carried external eggs, and this percentage was much lower than the $76.5 \%$ 92.3\% found in December 1975 in Yemen (Sanders, 1981). Given that only a December sample existed from Oman, no further inferences could be made on reproductive seasonality.

The smallest egg-bearing female had a CL of 74 $\mathrm{mm}$, and the $\mathrm{L}_{50}$ estimated from the logistic curve, based on gonad stages, was $54 \mathrm{~mm}$. Sanders (1981) reported a smallest egg-bearing female of $57 \mathrm{~mm} \mathrm{CL}$. The lower value obtained from the Oman sample is based on a very small sample size in the smallest size classes, and is likely an underestimate.

The range extension shown for $P$. sewelli into the waters of Oman is perhaps not surprising, given that it inhabits the continental slope of the Arabian Sea off Yemen, and that a similar deeper-water environment extends northeastwards to Ras al Hadd. Possibly, its presence off southern Oman remained unknown because the steep and often rocky continental slope between the Yemen/Oman border and Mirbat is not exploited by trawlers. The potential commercial value of $P$. sewelli off Oman should be further investigated through experimental fishing.

\section{Acknowledgement}

The research was based on data collected during the Fish Resources Assessment Survey of the Arabian Sea Coast of Oman. We are grateful to Dr. Hamed AlOufi (Under-Secretary, Ministry of Fisheries Wealth) and Dr. Ahmed Al-Hosni (DG for Fisheries Research and Extension) for commissioning the survey and supporting the associated research projects. We thank the crew and scientists aboard the survey vessel $\mathrm{Al}$ Mustaqila for providing the samples.

\section{References}

Anon. 2004. Fisheries Statistics Book (2003) for the Republic of Yemen. General Department for Planning and Statistics, Ministry of Fish Wealth, Sana'a. 224 pp.

Fischer, W. and G. Bianchi. 1984. FAO species identification sheets for fishery purposes. Western Indian Ocean (Fishing Area 51). Prepared and printed with the support of the Danish International Development Agency (DANIDA). Rome, Food 
and Agricultural Organization of the United Nations, Vols. 1-6:pag.var.

Groeneveld, J.C. 1996. Morphometric relationships of palinurid lobsters Palinurus delagoae and P. gilchristi and a scyllarid lobster Scyllarides elisabethae caught in traps off the south and east coasts of South Africa. South African Journal of Marine Science, 17: 329-334.

Groeneveld, J.C. and R. Melville-Smith. 1994. Size at onset of sexual maturity in the South Coast rock lobster, Palinurus gilchristi (Decapoda: Palinuridae) from South African Journal of Marine Science, 14:219-223.
Holthuis, L.B. 1991. FAO Species Catalogue. 13. Marine lobsters of the world. An annotated and illustrated catalogue of species of interest to fisheries known to date. FAO Fisheries Synopsis, 125(13), $292 \mathrm{pp}$.

Johnsen, T. 1985. Commercial trawling for fish and deep sea lobster (Puerulus spp.) off Somalia. FAO, Rome, RAF/79/065/WP/13/84. 42 pp. www.fao.org/docrep/field/255099.htm.

Sanders, M.J. 1981. Preliminary stock assessment for the deep sea lobster Puerulus sewelli taken off the coast of the People's Democratic Republic of Yemen. FAO, Rome, RAB/77/008/18. 48pp. 